\title{
Interferon- $\alpha$ resistance in renal carcinoma cells is associated with defective induction of signal transducer and activator of transcription I which can be restored by a supernatant of phorbol 12-myristate 13-acetate stimulated peripheral blood mononuclear cells
}

\author{
A Brinckmann', S Axer', D Jakschies², I Dallmann', J Grosse', T Patzelt ${ }^{3}$, T Bernier², A Emmendoerffer ${ }^{2}$ and \\ J Atzpodien*,1,3,4
}

'Department of Hematology and Oncology, Medizinische Hochschule, Hannover, Germany; ${ }^{2}$ Fraunhofer Institut, Hannover, Germany; ${ }^{3}$ European Institute for Tumor-Immunology and Prevention (EUTIP), 152 Gotenstr., 53175, Bonn, Germany; ${ }^{4}$ Fachklinik Hornheide of the University of Münster, Münster-

Handorf, Germany

Therapy of selected human malignancies with interferon- $\alpha$ is widely accepted but often complicated by the emergence of interferon- $\alpha$ resistance. Interferon is a pleiotropic cytokine with antiproliferative, antitumour, antiviral and immunmodulatory effect; it signals through the Jak-STAT signal transduction pathway where signal transducer and activator of transcription I plays an important role. Here we report both, a lack of signal transducer and activator of transcription induction in interferon- $\alpha$ resistant renal cell carcinoma cells and signal transducer and activator of transcription I reinduction of phorbol I2-myristate 13-acetate-stimulated peripheral blood mononuclear cells supernatant. Preliminary experiments on the identification of the molecules that reinducing signal transducers and activators of transcription I indicate that interferon- $\gamma$ may be the responsible candidate cytokine, but several others may be involved as well. This work provides the basis for therapeutic strategies directed at the molecular modulation of interferon- $\alpha$ resistance in human neoplasms.

British Journal of Cancer (2002) 86, 449 -455. DOI: I0.1038/sj/bjc/6600066 www.bjcancer.com

(c) 2002 The Cancer Research Campaign

Keywords: cytokine; signal transduction pathway; Jak; cancer therapy

Interferon- $\alpha($ IFN- $\alpha)$ plays an important role in the treatment of various human malignancies, among them renal cell carcinoma (Dorr, 1993); however, response to IFN- $\alpha$ is often impaired by the development of IFN-resistance (Devita et al, 1989), mechanisms of which are poorly understood.

Interferon- $\alpha$ belongs to a group of cytokines with antiviral, antiproliferative, antitumour and immunmodulatory activities (Pestka et al, 1987). Binding of IFN- $\alpha$ to the IFN Type I receptor results in oligomerization of the receptor subunits and subsequent transphosphorylation of receptor-associated Janus-kinases Jak1 and Tyk2; activated Jak1 and Tyk2 subsequently phosphorylate tyrosine residues on the associated receptor chain. Signal transducers and activators of transcription (STAT) 1 and 2 can then bind to the receptor by their $\mathrm{SH} 2$ domains which are thereupon tyrosine phosphorylated by the receptor-associated Janus-kinases; thereafter, the STATs are released from the receptor and form STAT1-STAT2heterodimers which translocate to the nucleus where they bind with $\mathrm{p} 48$ to form the interferon stimulated gene factor 3 (ISGF3). ISGF3 binds to the interferon stimulated response element (ISRE)

*Correspondence: Professor J Atzpodien;

E-mail: SekrProfAtzpodien@yahoo.de

Received I6 May 200I; revised 29 October 200I; accepted 8 November 2001 in the promoter of IFN-induced genes resulting in transcription of interferon-stimulated genes (ISG) (Schindler and Darnell, 1995; Haque and Williams, 1998).

There is evidence that IFN- $\alpha$ resistance is associated with defective components of the Jak-STAT-Pathway (Pansky et al, 2000) e.g., defective activation of ISGF3 (Xu et al, 1994; Wong et al, 1997), lack of STAT1 expression (Sun et al, 1998) or STAT3 induction (Yang et al, 1998). It has been reported that sequential treatment of interferon resistant cells with retinoic acid or tamoxifen followed by interferon- $\alpha$ up-regulates STAT1 expression and ISGF3 activation, respectively, in cells which do not respond to either single agent (Kolla et al, 1996; Lindner et al, 1997).

Here we sought (a) to characterize STAT1 deficiency associated with IFN- $\alpha$ resistance and (b) to identify modulators of STAT1 induction. These studies provide the basis for a potential modulation of resistance to IFN- $\alpha$ in renal cell carcinoma ex-vivo as well as in renal cell carcinoma patients receiving systemic IFN- $\alpha$.

\section{MATERIALS AND METHODS}

\section{Cells and culture conditions}

A-498 and Caki-2 cells were obtained from ATCC (Rockville, USA) (Cat. No. HTB 44). The fresh RCC cells were established according to Ebert et al (1990). Cells were grown in RPMI 1640 supplemen- 
ted with $10 \%$ heat-inactivated FCS, $2 \mathrm{mM}$ L-glutamine, $50 \mathrm{mg} \mathrm{ml}^{-1}$ streptomycin and $50 \mathrm{IU} \mathrm{ml}^{-1}$ penicillin at $37^{\circ} \mathrm{C}$ in an atmosphere containing $5 \% \mathrm{CO}_{2}$ and passaged once a week.

\section{Reagents}

Interferon- $\alpha$-2a (Roferon $\mathrm{A}^{\circledR}\left(18 \times 10^{6} \mathrm{IU}\right)$, Hoffmann-LaRoche, Basel, Switzerland) was dissolved in Aqua bidest, diluted with RPMI 1640 and stored in aliquots of $1 \times 10^{6}$ IU at $4^{\circ} \mathrm{C}$. IFN- $\alpha$ was used in a final concentration of $1000 \mathrm{IU} \mathrm{ml}^{-1}$. IFN- $\gamma-1 \mathrm{~b}$ $\left(\right.$ Imukin $\left.{ }^{\circledR}\left(3 \times 10^{6} \mathrm{IU}\right)\right)$ was obtained from Boehringer Ingelheim, dissolved in Aqua bidest and stored in aliquots of $10 \mathrm{ng} \mathrm{ml}^{-1}$ $\left(300 \mathrm{IU} \mathrm{ml}^{-1}\right)$ at $4^{\circ} \mathrm{C}$. Phorbol 12-myristate 13-acetate (PMA) was obtained from Sigma. It was dissolved in DMS and stored as aliquots $\left(10 \mu \mathrm{g} \mathrm{ml}^{-1}\right)$ at $4^{\circ} \mathrm{C}$.

\section{Interferon- $\alpha-2 a$ dose titration}

Cells were tested for IFN- $\alpha$ resistance using different IFN- $\alpha-2 \mathrm{a}$ concentrations $\left(10,100,1000,10000 \mathrm{IU} \mathrm{ml}^{-1}\right)$ in the Cell Proliferation ELISA, BrdU (colorimetric), (Roche Molecular Biochemicals, Mannheim, Germany).

A relative resistance to the antiproliferative effects of interferon$\alpha$ was best produced by continuous incubation of the A-498 and fresh renal cell carcinoma (RCC) cells with $1000 \mathrm{IU} \mathrm{ml}^{-1}$ interferon- $\alpha$ over $3-4$ months.

\section{Preparation of PMA-stimulated PBMC supernatant}

Peripheral blood mononuclear cells (PBMC) were isolated from buffy-coat leucocyte concentrates of healthy donors by Ficoll gradient centrifugation. The cells were cultured in RPMI 1640 supplemented as indicated above and stimulated with $10 \mathrm{ng} \mathrm{ml}^{-1}$ PMA for 4 days. After centrifugation for $10 \mathrm{~min}$ at $225 \mathrm{~g}$ the media was decanted and again centrifuged for $10 \mathrm{~min}$ at $2000 \mathrm{~g}$. The supernatant was diluted $1: 2$ with RPMI 1640 and added to the cells.

\section{Whole cell extracts}

Cells were treated with IFN- $\alpha$, IFN- $\gamma$ and supernatant as single agents, as well as with combinations of IFN- $\alpha$ and supernatant for various times as indicated in Figures $1-5,7$. IFN- $\alpha$ or IFN- $\gamma$ was added during the last $30 \mathrm{~min}$ of incubation with supernatant. Cells were washed with ice-cold phosphate-buffered saline (PBS) and resuspended in RSB buffer (10 mM Tris ( $\mathrm{pH} 7.4$ ); $10 \mathrm{mM} \mathrm{NaCl} ; 1.5 \mathrm{mM}$ $\mathrm{MgCl}_{2} ; 10 \mathrm{~mm} \mathrm{NaF}$; supplemented with $0.15 \mathrm{mM}$ PMSF; $1 \mathrm{~mm}$ DTT; $0.2 \mathrm{mM} \mathrm{Na}_{3} \mathrm{VO}_{4}$ ) and incubated $10 \mathrm{~min}$ on ice for swelling. After centrifugation at $15800 \mathrm{~g}$ for $10 \mathrm{~s}$ at $4^{\circ} \mathrm{C}$, cells were resuspended in buffer C (20 mM HEPES; $420 \mathrm{~mm} \mathrm{NaCl} ; 1.5 \mathrm{mM} \mathrm{MgCl}_{2}$; $0.2 \mathrm{mM}$ EDTA; 25\% Glycerin; $10 \mathrm{mM} \mathrm{NaF}$; supplemented with $0.15 \mathrm{~mm}$ PMSF; $1 \mathrm{mM}$ DTT; $0.2 \mathrm{~mm} \mathrm{Na} \mathrm{VO}_{4}$ ), sucked up and down $5-10$ times in a $26 \mathrm{G}$ syringe and incubated on ice for $45 \mathrm{~min}$. Whole cell extract was obtained by centrifugation at $15800 \mathrm{~g}$ for $10 \mathrm{~min}$ at $4^{\circ} \mathrm{C}$. The supernatant (=whole cell extract) was shock frozen in liquid nitrogen at $-175^{\circ} \mathrm{C}$ and stored at $-80^{\circ} \mathrm{C}$ until use.

\section{Electrophoretic mobility shift assay (EMSA)}

As STAT1 binding site we used the $\beta$-Casein $\left(5^{\prime}\right.$-TCGAAGATTTCTAGGAATTCAATC- $3^{\prime}$ ) or Fc $\gamma$ RI-GAS (5'-TCGATTTGAGATGTATTTCCCAGAA- $\left.3^{\prime}\right)$. The oligos were synthesized at Roth, Karlsruhe, Germany and labelled at the $5^{\prime}$-end with ${ }^{32} \mathrm{P}$. Briefly whole cell extracts of equal protein concentration were incubated with the labelled oligo in $200 \mathrm{mM} \mathrm{KCl} ; 2 \mathrm{mM} \mathrm{MgCl}_{2} ; 0.5 \mathrm{~mm}$ EGTA; $2.5 \mathrm{mM}$ DTT; $100 \mathrm{mM}$ HEPES (pH 7.9); 50\% Glycerine and Poly-d(I-C) for $30 \mathrm{~min}$ at room temperature. For competition assays $1 \mu \mathrm{l}$ monoclonal STAT1-antibody (Santa Cruz Biotechnology, Inc.) or 50-, 100- and 300-fold excess of unlabelled oligo

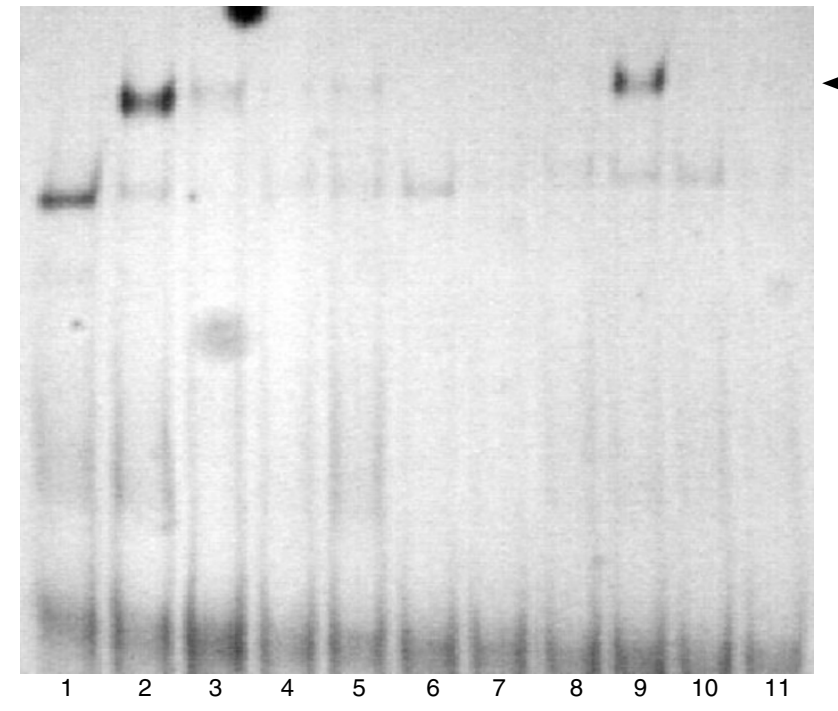

Figure I Electrophoretic mobility shift assays for IFN- $\alpha$ induced STATI induction. IFN- $\alpha$ sensitive (S) and IFN- $\alpha$ resistant (R) A-498 and fresh RCC cells and Caki-2 cells were either left untreated or incubated with $1000 \mathrm{IU} \mathrm{ml} \mathrm{m}^{-1} \mathrm{IFN}-\alpha$ for $30 \mathrm{~min}$. Lanes I-5 are A-498 cells: lanes I and 4 , untreated IFN- $\alpha$ sensitive and resistant cells, respectively; lanes 2, 3 and 5, IFN- $\alpha$ stimulated IFN- $\alpha$ sensitive and resistant cells, respectively. Lanes 6 and 7 are Caki-2 cells: lane 6, untreated Caki-2 cells; lane 7, IFN- $\alpha$ stimulated cells. Lanes 8 - II are fresh RCC cells: lanes 8 and I0, untreated IFN- $\alpha$ sensitive and resistant cells, respectively; lanes 9 and II, IFN- $\alpha$ stimulated IFN- $\alpha$ sensitive and resistant cells, respectively. STATI induction can be detected in sensitive A-498 and fresh RCC cells after stimulation with IFN- $\alpha$ but not in resistant cells (lanes 2 and 9). STATI can be competed with monoclonal anti-STATI antibody (lane 3) (see arrow for STATI band).

were used. Electrophoresis was performed on a $6 \%$ non-denaturating polyacrylamide gel at $300 \mathrm{~V}$ for $15 \mathrm{~min}$ and $380 \mathrm{~V}$ for $2 \mathrm{~h}$ in the cold. Gels were dried and exposed to X-Omat AR 5 films (Kodack, Stuttgart, Germany) for 1 to 3 days.

\section{STAT1-reinduction experiments of $\gamma$-interferon}

Based on experiments of Venkataraman et al (1999) IFN- $\gamma-1 b$ was used in a concentration of $10 \mathrm{ng} \mathrm{ml}^{-1}$. Experiments were performed in duplicate.

\section{Statistical analysis}

Assays were regularly performed in triplicates and statistical means were established.

\section{RESULTS}

\section{IFN- $\alpha$ associated antiproliferative effect and STAT1 induction in RCC cells}

The RCC cell lines A-498 and Caki-2 and fresh RCC cells were assessed for the antiproliferative effect of IFN- $\alpha$ by a cell proliferation ELISA based on BrdU incorporation. In A-498 and fresh RCC cells, IFN- $\alpha$ inhibited cell proliferation in a dose-dependent manner while in Caki- 2 cells, IFN- $\alpha$ showed no antiproliferative effect (data not shown).

As IFN- $\alpha$ is known to induce STAT1 in various cell types, cells were investigated for STAT1 induction. Cells were incubated for $30 \mathrm{~min}$ with $1000 \mathrm{IU} \mathrm{ml}^{-1}$ interferon- $\alpha$ and assessed for STAT1 induction by EMSA. We found that in A-498 and fresh RCC cells IFN $-\alpha$ induced STAT1 but not in Caki- 2 cells, suggesting that 
A

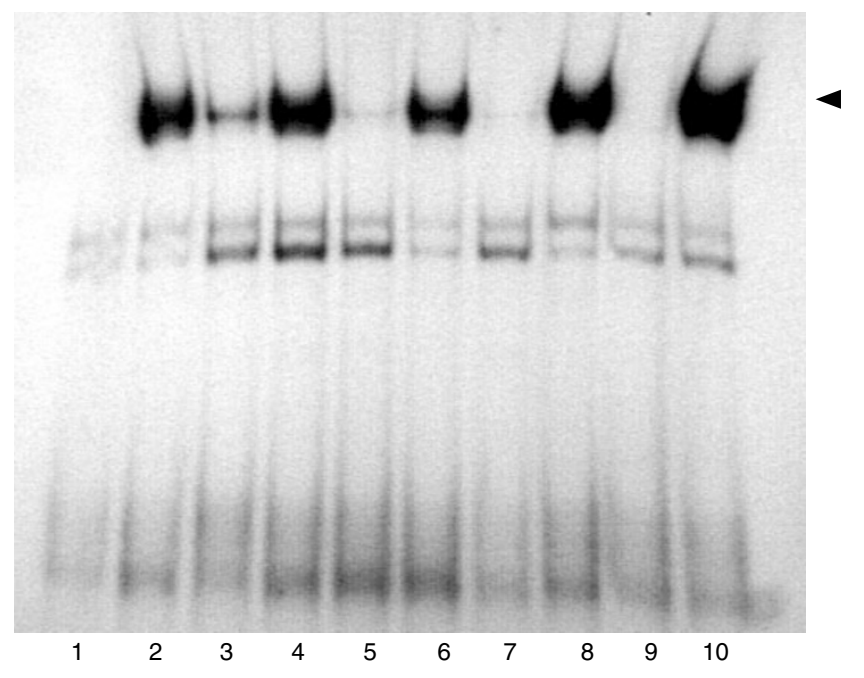

B

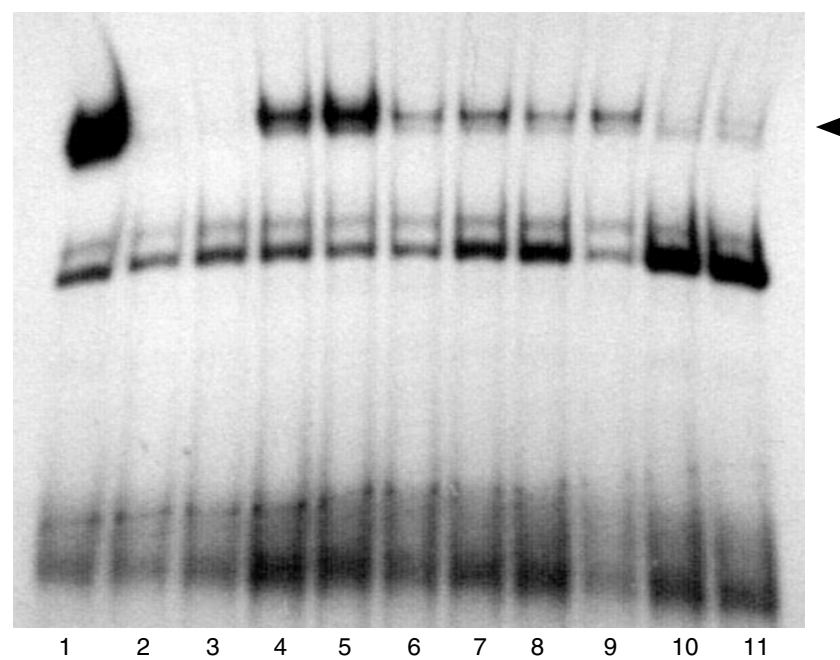

Figure 2 Electrophoretic mobility shift assays for STATI induction in A498 cells by PMA-stimulated PBMC supernatant. (A) Electrophoretic mobility shift assay for STATI induction in IFN- $\alpha$ sensitive (S) A-498 cells by PMA-stimulated PBMC supernatant. Cells were either left untreated (lane I) or treated with IFN- $\alpha$ alone (lane 2) or supernatant alone (lanes 3, 5, 7, 9) or with their combination (lanes 4, 6, 8 and 10). STATI is induced in the presence of IFN- $\alpha$ (lanes 2, 4, 6, 8 and I0) and after incubation for I $\mathrm{h}$ with the supernatant (lane 3) (see arrow for STATI band). (B) STATI induction in IFN- $\alpha$ resistant (R) A-498 cells by PMA-stimulated PBMC supernatant. Cells were treated with IFN- $\alpha$ alone (lane 3 ) or supernatant alone (lanes 4, 6, 8 and 10) or with their combination (lanes 5, 7, 9 and II). IFN- $\alpha$ does not induce STATI (lane 3) but treatment with supernatant alone and in combination with IFN- $\alpha$ for I, 4 and $6 \mathrm{~h}$ can induce STATI induction (lanes $4-9$ ). IFN- $\alpha$ treated A-498 S cells served as positive control (lane I) (see arrow for STATI band).

primary resistance towards the antiproliferative effect of IFN- $\alpha$ is associated with defective STAT1 induction (Figure 1).

Identity of STAT1 was confirmed by adding STAT1-mAb which selectively blocked the STAT1-band.

\section{IFN- $\alpha$ resistant $\mathrm{A}-498$ and $\mathrm{RCC}$ cells are defective in the induction of STAT1}

IFN- $\alpha$ resistance of A-498 and fresh RCC cells, respectively, was induced by culturing the cells over $3-4$ months in $1000 \mathrm{IU} \mathrm{ml} \mathrm{m}^{-1}$
A

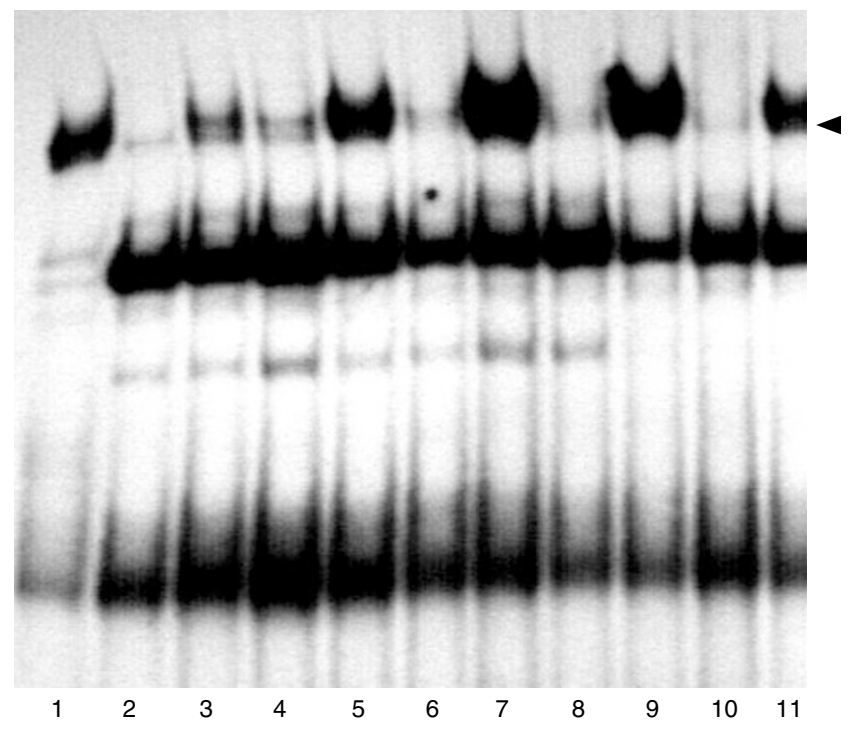

B

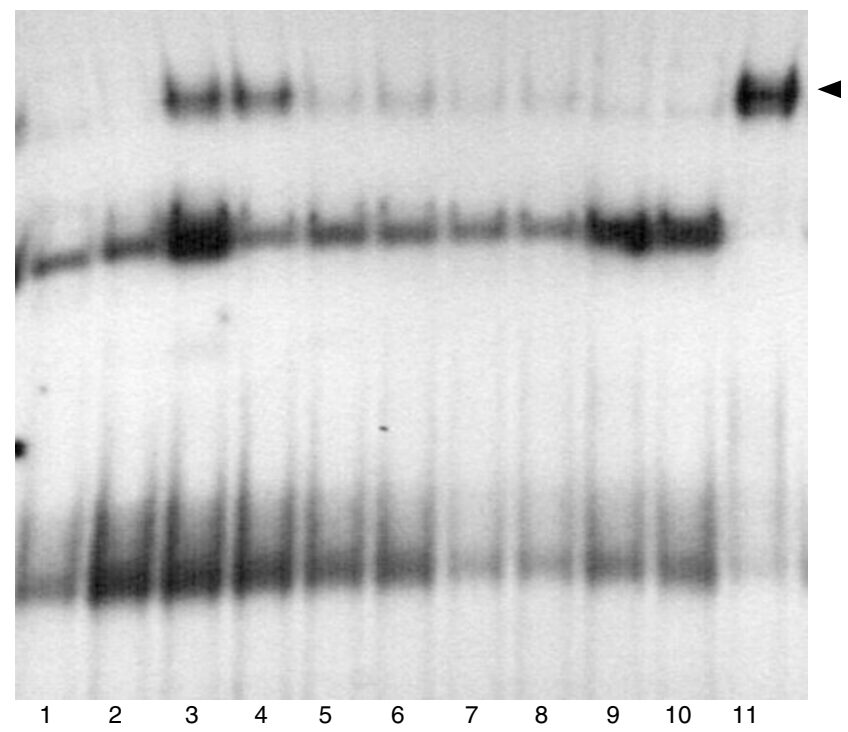

Figure 3 Electrophoretic mobility shift assays for STATI induction in fresh RCC tumour cell culture by PMA-induced PBMC supernatant. (A) STATI induction in IFN- $\alpha$ sensitive (S) fresh RCC tumour cell culture by PMA-induced PBMC supernatant. Cells were either left untreated (lane 2) or treated with IFN- $\alpha$ alone (lane 3) or supernatant alone (lanes 4, 6, 8 and 10 ) or with their combination (lanes 5, 7, 9 and II). STATI is induced in the presence of IFN- $\alpha$ (lane 3, 5, 7, 9 and II) and after incubation for I $\mathrm{h}$ with the supernatant (lane 4). IFN- $\alpha$ treated A-498 S cells served as positive control (lane I) (see arrow for STATI band). (B) STATI induction in IFN- $\alpha$ resistant (R) fresh RCC cells by PMA-stimulated PBMC supernatant. Cells were either left untreated (lane I) or were treated with IFN- $\alpha$ alone (lane 2) or supernatant alone (lanes 3, 5, 7 and 9) or with their combination (lanes 4, 6, 8 and I0). IFN- $\alpha$ did not induce STATI (lane 2) but treatment with supernatant alone and in combination with IFN- $\alpha$ for I $h$ induced STATI induction (lanes 3 and 4). IFN- $\alpha$ treated A-498 S cells served as positive control (lane II) (see arrow for STATI band).

IFN- $\alpha$. A relative resistance to IFN- $\alpha$ in A-498 and fresh RCC cells was subsequently confirmed by cell proliferation ELISA.

An EMSA for determination of STAT1 activity was performed as indicated above. IFN- $\alpha$ failed to induce STAT1 induction in resis- 
tant A-498 and fresh RCC cells, but not in IFN- $\alpha$ sensitive A-498 and fresh RCC cells, respectively (Figure 1).

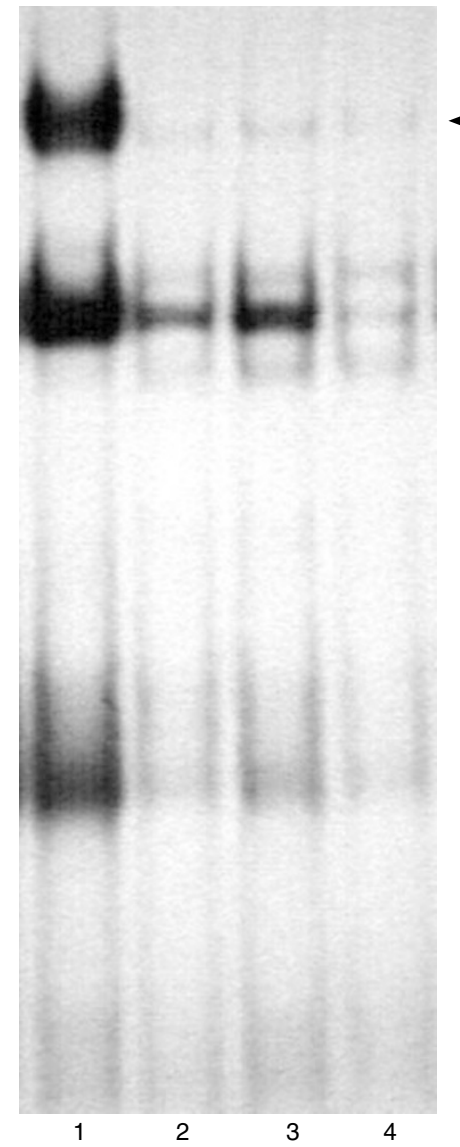

Figure 4 Electrophoretic mobility shift assay for STATI induction in Caki-2 cells by PMA-induced PBMC supernatant. Lanes $2-4$ are Caki-2 cells: Lane 2 are untreated Caki-2 cells. Cells were treated with supernatant alone (lane 3 ) or with IFN- $\alpha$ and supernatant (lane 4). There is no STATI induction detectable in Caki-2 cells. IFN- $\alpha$ treated A-498 $\mathrm{S}$ cells served as positive control (lane I) (see arrow for STATI band).
PMA-stimulated PBMC supernatant can reinduce STAT1 in IFN- $\alpha$ resistant A-498 and fresh RCC cells

The supernatant was prepared as described below. A-498 cells were treated for 1, 4, 6 and $24 \mathrm{~h}$ either with the supernatant alone or with supernatant followed by $30 \mathrm{~min} 1000 \mathrm{IU} \mathrm{ml}{ }^{-1}$ interferon- $\alpha$ as indicated in Figure 2A,B.

In the sensitive cells, the supernatant alone induced a visible band after $1 \mathrm{~h}$ of incubation, only. In the presence of IFN- $\alpha$, a STAT1-band was detectable at all time points (Figure 2A). The supernatant alone and its combination with IFN- $\alpha$ were able to restore STAT1 induction in resistant cells. The most intense STAT1-band was detected after $1 \mathrm{~h}$ of stimulation, it was significantly less intense 4 and $6 \mathrm{~h}$ and disappeared at $24 \mathrm{~h}$ (Figure $2 \mathrm{~B})$. When repeated with the PBMC supernatant of another donor, this assay led to the identical results (data not shown).

As we sought to exclude a cell line specific effect of the supernatant, we treated fresh RCC cells in the same manner. These cells were first derived from one RCC patient, and an IFN- $\alpha$ resistant variant which also lacks STAT1 induction was subsequently generated.

In sensitive cells, the supernatant alone induced a weak STAT1band after only $1 \mathrm{~h}$. As expected in the presence of interferon- $\alpha$, STAT1 was induced at all time points (Figure 3A). The present supernatant reinduced STAT1 in the IFN- $\alpha$ resistant cells with a clearly detectable band after $1 \mathrm{~h}$ (Figure 3B); Interferon- $\alpha$ treated A-498 S cells served as positive control for STAT1.

\section{In Caki-2 cells, PMA-stimulated PBMC supernatant cannot reinduce STAT1}

As the supernatant induced optimal STAT1 in A-498 and fresh RCC cells after $1 \mathrm{~h}$, Caki-2 cells were treated for $1 \mathrm{~h}$ with supernatant alone or in combination with IFN- $\alpha$. Neither the supernatant alone nor its combination with interferon reinduced STAT1 in Caki-2 cells (Figure 4 ).

\section{Confirmation of supernatant-induced STAT1 via competition with STAT1-mAb and unlabelled oligo}

To confirm that the band induced by the present supernatant correlated to STAT1, a competitional assay was performed with STAT1-mAb and with 50-, 100- and 300-fold excess of unlabelled oligo, which all blocked the STAT1-band (Figure 5).

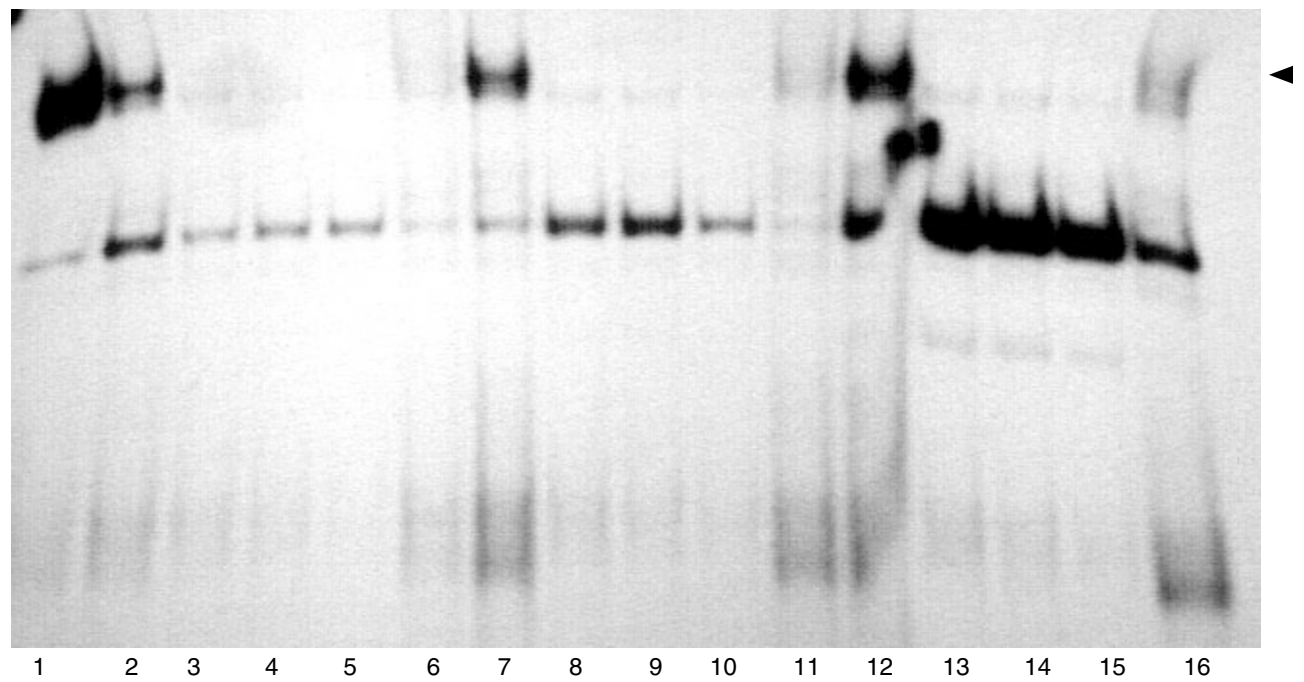

Figure 5 Confirmation of supernatant-induced STATI via competition with STATI-mAb and unlabelled oligo. Supernatant-induced STATI induction in IFN- $\alpha$ sensitive (S) A-498 cells (lane 2) and IFN- $\alpha$ resistant (R) A-498 cells (lanes 7 and I2) can be competed with STATI -mAb (lanes 6, II and I6) or 50-, 100 - and 300-fold excess of unlabelled oligo (lanes 3-5, 8- II, I3-15) (see arrow for STATI band). 
A

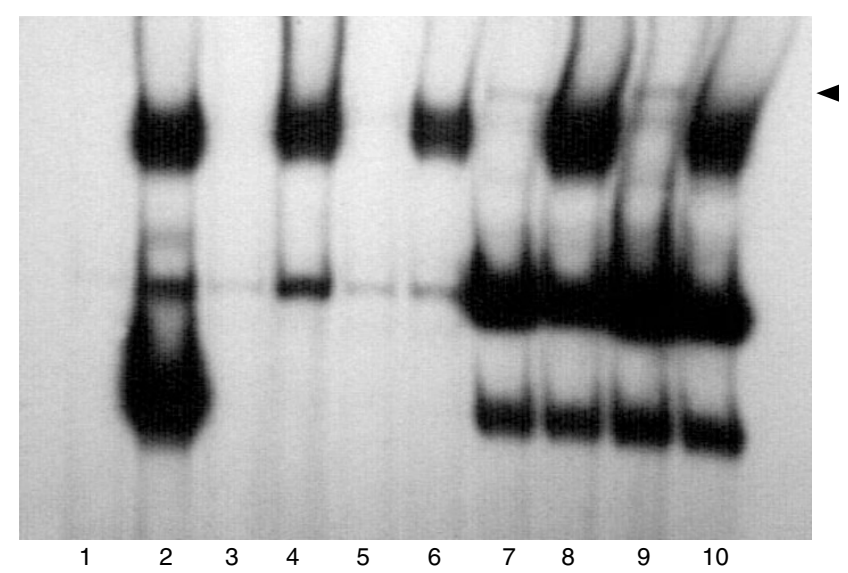

B

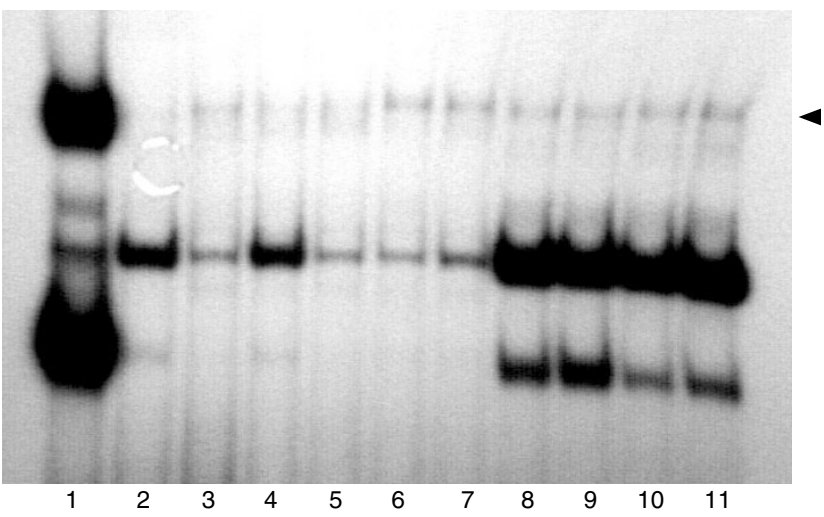

Figure 6 Electrophoretic mobility shift assays for STATI induction by $10 \mathrm{ng} \mathrm{ml^{-1 }}$ PMA. (A) STATI induction in IFN- $\alpha$ sensitive (S) A-498 cells by $10 \mathrm{ng} \mathrm{ml}{ }^{-1}$ PMA. Cells were either left untreated (lane I) or were treated with IFN- $\alpha$ alone (lane 2) or PMA alone (lanes 3, 5, 7 and 9) or with their combination (lanes 4, 6, 8 and 10). STATI indiction can be detected after incubation with IFN- $\alpha$ alone (lane 2) and in combination with PMA (lanes 4, 6, 8 and 10). PMA alone does not induce STATI (lanes 3, 5, 7, 9) (see arrow for STATI band). (B) STATI induction in IFN- $\alpha$ resistant (R) A-498 cells by $10 \mathrm{ng} \mathrm{ml}^{-1}$ PMA. Cells were either left untreated (lane 2) or were treated with IFN- $\alpha$ alone (lane 3 ) or PMA alone (lanes 4, 6, 8 and I0) or with their combination (lanes 5, 7, 9 and II). IFN- $\alpha$ and PMA alone as well as their combination fail to induce STATI in resistant cells. IFN- $\alpha$ treated A-498 S cells were used as positive control (lane I) (see arrow for STATI band).

PMA alone or in combination with interferon- $\alpha$ does not induce STAT1

In order to demonstrate that the effect of STAT1 reinduction was due to the cytokines secreted by PMA-stimulated PBMC and not by PMA itself, A-498 cells were incubated with $10 \mathrm{ng} \mathrm{ml}^{-1}$ of PMA either alone and in combination with IFN- $\alpha$. PMA alone did not induce STAT1 neither in the sensitive nor in the resistant cells, while the combination of PMA and IFN- $\alpha$ induced STAT1 in the sensitive cells, but not in the resistant cells (Figure 6A,B).

\section{IFN- $\gamma$ alone does induce STAT1}

To investigate the cytokine potentially capable of STAT1 reinduction, IFN- $\alpha$ resistant A-498 cells were incubated with IFN- $\gamma$ 1b $\left(10 \mathrm{ng} \mathrm{ml}^{-1}\right)$, which clearly reinduced STAT1. A-498 sensitive and resistant cells treated with IFN- $\alpha$ were used as positive and negative control for STAT1 (Figure 7).

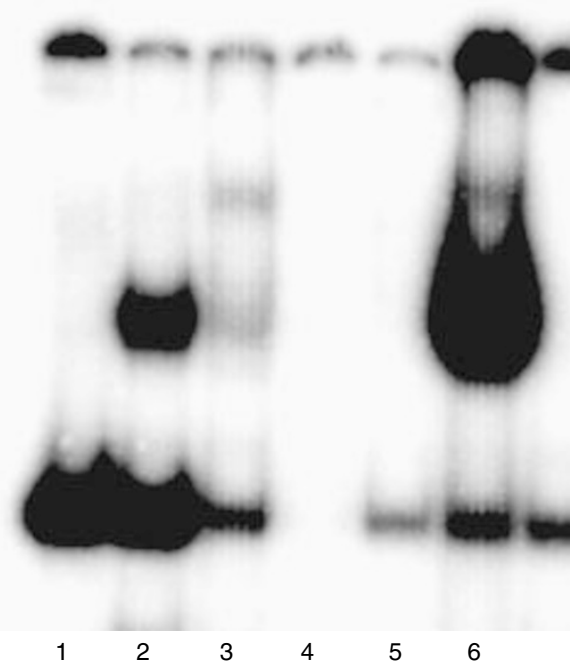

Figure 7 Sensitive (S) cells were either left untreated (lane I) or were treated with IFN- $\alpha$ alone (lane 2) or with the combination of IFN- $\alpha$ and a monoclonal STATI antibody (lane 3). Resistant (R) cells were either left untreated (lane 4) or were treated with IFN- $\alpha$ alone (lane 5) or with IFN- $\gamma$ alone (lane 6). IFN- $\alpha$ fail to induce STATI in resistant cells (but it was possible to induce STATI in the sensitive cells). The signal extinguished in sensitive cells when a commercially available monoclonal STATI antibody was added (lane 3). In contrast IFN- $\gamma$ was able to reinduce STATI in IFN- $\alpha$ resistant cells (lane 6). Untreated A-498 S and R cells were used as negative controls (lanes I and 4).

\section{DISCUSSION}

Response to IFN- $\alpha$ is often impaired by the development of IFNresistance (Devita et al, 1989). Many mechanisms have been proposed to mediate IFN- $\alpha$ resistance in various different cell types: lack of ISGF3 (Xu et al, 1994; Wong et al, 1997) or one of its components (Dron and Tovey, 1993; Sun et al, 1998), decrease in ISG expression (Affabris et al, 1983; Salzberg et al, 1983), lack of a high affinity receptor site (Hannigan et al, 1984) or the development of anti-interferon antibodies in patients (Quesada et al, 1985; Steis et al, 1988). However, there seems to be no unique mechanism for all cells given reports on interferon-resistant cells which do not inherit one of the above defects (Grups and Bange, 1990; Talpaz et al, 1992). While an interferon-resistant cell line with entire STAT1 induction has been reported (Yang et al, 1998), STAT1 seems to be an essential component of interferon signalling as STAT1 deficient mice do not respond to interferons and are highly sensitive toward viral infections (Durbin et al, 1996; Meraz et al, 1996); in addition complementation of the IFN-unresponsive mutant cell line U3 interferon with STAT1, cDNA constructs reportedly restores ISGF3 formation and transcriptional response to interferon (Müller et al, 1993).

Here, we detected a deficient STAT1 induction in two different RCC sublines, with secondary interferon- $\alpha$ resistance and in a primary resistant RCC cell line. There were several possibilities to explain the defect, e.g.: (a) decreased synthesis, increased degradation, decreased tyrosine phosphorylation of STAT1; (b) malfunction in the preceding steps of the signal transduction pathway; or (c) lack of STAT1 transcript due to a mutation in the STAT1 gene.

In the present experiments, the PMA-stimulated PBMC supernatant reinduced STAT1 in A-498 and fresh RCC cells with secondary IFN- $\alpha$ resistance but not in primary resistant Caki- 2 cells. This indicated that in resistant A-498 and fresh RCC cells, the STAT1 
gene is still intact while in primary resistant Caki-2 cells, the defect in the signal transduction pathway appears to be more extensive. Previously, Sun et al (1998) reported a lack of STAT1 transcript in IFN resistant lymphoma cells. Here a mutation in or a loss of the STAT1 gene could explain why Caki-2 cells were refractory to PMA-PBMC-mediated STAT-reinduction.

It is known that PMA-stimulated PBMC produce a number of cytokines; as observed there are several cytokines including IL-2, IL-6, IL-9, IL-10, IL-11, IFN- $\gamma$, hormones as growth hormone and prolactin and growth factors as GCSF, EGF, PDGF, CSF-1 and angiotensin which may induce STAT1 in various cell types (Schindler and Darnell, 1995; Briscoe et al, 1996; Ihle, 1996; Leaman et al, 1996).

Here, we demonstrated that IFN- $\gamma$ reinduces STAT1 in IFN- $\alpha$ resistant A-498 cells; this suggested that IFN- $\gamma$ may be the PMAstimulated PBMC derived cytokine capable of reinducing STAT1 but several others may be involved as well. Since biological effects of IFN- $\alpha$ and IFN- $\gamma$ are both mediated by Jak1, it appeared that Tyk2 tyrosine kinase or the receptor may be impaired in IFN- $\alpha$ resistant carcinoma cells upstream of STAT1.

The significance of the additional STAT1 inducers remained unclear as their biological effects are not necessarily mediated by

\section{REFERENCES}

Affabris E, Romeo G, Belardelli F, Jemma C, Mechti N, Gresser I, Rossi GB (1983) 2-5A synthetase activity does not increase in interferon-resistant Friend leukemia cell variants treated with alpha/beta interferon despite the presence of high-affinity interferon receptor sites. Virology 125: $508-$ 512

Briscoe J, Guschin D, Rogers NC, Watling D, Müller M, Horn F, Heinrich P, Stark GR, Kerr IM (1996) JAKs, STATs and signal transduction in response to the interferons and other cytokines. Phil Trans R Soc Lond B 351: 167 171

Devita Jr VT, Hellmann S, Rosenberg SA (eds) (1989) In Cancer: principles and practices of oncology. 3rd edn pp 995-998 Philadelphia: Lippincott

Dorr RT (1993) Interferon- $\alpha$ in malignant and viral diseases. Drugs 45: $177-$ 211

Dron M, Tovey MG (1993) Interferon-resistant Daudi cells are deficient in interferon-alpha-induced ISGF3 alpha activation, but remain sensitive to the interferon-alpha-increase in the ISGF3 gamma content. J Interferon Res 13: $377-383$

Durbin JE, Hackenmiller R, Simon MC, Levy DE (1996) Targeted disruption of the mouse STAT1 gene results in compromised innate immunity to viral disease. Cell 84: $443-450$

Ebert T, Bander HN, Finstad CL, Ramsawak RD, Old LJ (1990) Establishment and characterization of human renal cancer and normal kidney cell lines. Cancer Res 50: $5531-5536$

Grups JW, Bange FC (1990) Interferon-receptors on the surface of interferonsensitive and interferon-resistant urothelial carcinomas. Urol Res 18: 119 122

Han Y, Leaman DW, Watling D, Rogers NC, Groner B, Kerr IM, Wood WI, Stark GR (1996) Participation of Jak and STAT proteins in growth hormone-induced signaling. J Biol Chem 271: $5947-5952$

Hannigan GE, Gewert DR, Williams BRG (1984) Characterization and regulation of $\alpha$-interferon receptor expression in interferon-sensitive and -resistant human lymphoblastoid cells. J Biol Chem 259: 9456-9460

Haque SJ, Williams BRG (1998) Signal transduction in the interferon system. Semin Oncol 25(Suppl 1): 14-22

Ihle JN (1996) STATs: signal transducers and activators of transcription. Cell 84(3): $331-334$

Kolla V, Lindner DJ, Weihua X, Borden EC, Kalvakolanu DV (1996) Modulation of interferon (IFN) - inducible gene-expression by retinoic acid. Upregulation of STAT1 in IFN-unresponsible cells. J Biol Chem 271: $10508-$ 10514

Leaman GW, Leung S, Li X, Stark GC (1996) Regulation of STAT-dependent pathways by growth factors and cytokines. FASEB J 10: $1578-1588$

Lindner D, Kolla V, Kalvakolanu DV, Borden EC (1997) Tamoxifen enhances interferon-regulated gene expression in breast cancer cells. Molec Cell Biochem 167: $169-177$ a Jak-STAT signal transduction pathway or require STAT1 induction. Previously, STAT1 deficient mice responded normally to growth hormone, EGF and IL-10 which induce STAT1 in vitro (Meraz et al, 1996). STAT1 induction by cytokines other than interferons were cell-specific (Schindler and Darnell, 1995; Han et $a l, 1996)$. Therefore, in RCC some of these known cytokines may actually not be able to induce STAT1, while there might be additional inducers.

Future experiments will focus on further steps toward the identification of those molecular regulators associated with IFN- $\alpha$ resistance in order to provide new modalities of treatment for renal cell carcinoma patients.

\section{ACKNOWLEDGEMENTS}

J Atzpodien is supported by grants of Deutsche Krebshilfe, Wilhelm-Sander-Stiftung and Gesellschaft zur Förderung immunologischer Krebstherapien e.V.
Meraz MA, White JM, Sheehan KCF, Bach EA, Rodig SJ, Dighe AS, Kaplan D, Riley JK, Greenlund AC, Campbell D, Carver-Moore K, Dubois RN, Clark R, Aguet M, Schreiber RD (1996) Targeted disruption of the STAT1 gene in mice reveals unexpected physiologic specifity in the JAK-STAT signaling pathway. Cell 84: $431-442$

Müller M, Laxton C, Briscoe J, Schindler C, Improta T, Darnell JE, Stark GR, Kerr IM (1993) Complementation of a mutant cell line: central role of the $91 \mathrm{kDa}$ polypeptide of ISGF3 in the interferon $\alpha$ and $-\gamma$ signal transduction pathways. EMBO 12: $4221-4228$

Pansky A, Hildebrand P, Fasler-Khan E, Baselgia L, Ketterer S, Beglinger C, Heim MH (2000) Defective Jak-STAT signal transduction pathway in melanoma cells resistant to growth inhibition by interferon-alpha. Int $J$ Cancer 85: $720-725$

Pestka S, Langer JA, Zoon KC, Samuel CE (1987) Interferons and their actions. Ann Rev Biochem 56: $727-777$

Quesada JR, Rios A, Swanson D, Trown P, Gutterman JU (1985) Antitumor activity of recombinant-derived interferon alpha in metastatic renal cell carcinoma. J Clin Oncol 3: $1522-1528$

Salzberg S, Wreschner D, Oberman F, Panet A, Bakhanashvili M (1983) Isolation and characterization of an interferon-resistant cell line deficient in the induction of $\left(2^{\prime}-5^{\prime}\right)$ oligoadenylate synthetase activity. Mol Cell Biol 3: 1759- 1765

Schindler C, Darnell Jr JE (1995) Transcriptional response to polypeptide ligands: The JAK-STAT Pathway. Annu Rev Biochem 64: 621-651

Steis RG, Smith II JW, Urba WJ, Clark JW, Itri LM, Evans LM, Schoenberger C, Longo D (1988) Resistance to recombinant interferon-alpha-2a in hairy cell leukemia associated with neutralizing anti-interferon antibodies. $N$ Engl J Med 318: 1409-1413

Sun WH, Pabon C, Alsayed Y, Huang PP, Jandeska S, Uddin S, Platanias LC, Rosen ST (1998) Interferon- $\alpha$ resistance in a cutaneous T-cell lymphoma cell line is associated with lack of STAT1 expression. Blood 91: 570-576

Talpaz M, Chernajovski Y, Troutman-Worden K, Wetzler M, Kantarjian H, Gutterman JU, Kurzrock R (1992) Interferon-stimulated genes in interferon-sensitive and -resistant chronic myelogenous leukemia patients. Cancer Res 52: 1087-1090

Venkataraman C, Leung S, Salvekar A, Mano H, Schindler U (1999) Repression of IL-4-induced gene expression by IFN-gamma requires Stat activation. J Immunol 162(7): 4053-4061

Wong LH, Krauer KG, Hatzinisiriou I, Estcourt MJ, Hersey P, Tam ND Edmondson S, Devenish RJ, Ralph SJ (1997) Interferon-resistent human melanoma cells are deficient in ISGF3 components, STAT1, STAT2, and p48-ISGF3 $\gamma$. J Biol Chem 272: 28779-28785 
Xu B, Grander D, Sangfelt O, Einhorn S (1994) Primary leukemia cells resistant to alpha-interferon in vitro are defective in the activation of the DNA-binding factor interferon-stimulated gene factor 3. Blood 84: $1942-1949$
Yang CH, Murti A, Pfeffer LM (1998) STAT3 complements defects in an interferon-resistant cell line: evidence for an essential role for STAT3 in interferon signaling and biological activities. Proc Natl Acad Sci USA 95: $5568-5572$ 